DOI https://doi.org/10.30525/978-9934-26-180-0-11

\title{
ТЕМА ГОЛОДОМОРУ ТА ПОВОЄННОЇ ДІЙСНОСТІ У ТЕТРАЛОГІЇ «ТРУДОВА КНИЖКА МАТЕРІ» МИКОЛИ ТОМЕНКА (ДО 85-ЛІТТЯ ВІД ДНЯ НАРОДЖЕННЯ ПОЕТА)
}

\author{
Томенко О. М. \\ кандидат філологічних наук, \\ дочент кафедри культури та соціально-гуманітарних дисииплін \\ Національна академія образотворчого мистецтва і архітектури \\ м. Київ, Україна
}

Основною темою тетралогії «Трудова книжка матері» $є$ образне осмислення подій колективізації, голодомору-геноциду українського народу у період $30-50-\mathrm{x}$ років XX століття.

Ідея написання даної книги виникла із маленької трудової книги колгоспниці, матері поета, яку передали письменникові односельчани через 50 років. Цей документ фіксував зароблені трудодні у колгоспі в часи радянської колективізації. Але для поета він став справжнім потрясінням і відкриттям. За тими цифрами і датами він «...вивчав Матір» [3, с. 15]. Адже мати поета померла у віці 56 років від каторжної колгоспної праці. Але, як з'ясувалося згодом, після виступу поета на Українському радіо на початку 1990 років, за такою ж трудовою книжкою стояла доля всіх матерів України. Таких трудових книжок були мільйони, i кожна 3 них фіксувала рабську працю, запроваджену радянською системою у період колективізації. Позбавлені паспортів та засобів до існування, отримуючи або не отримуючи (в разі хвороби) пайку хліба чи зерна. Через усю поему трудова книжка матері проходить як реальний звинувачувальний документ і як узагальнений художній образ. Вона найчесніша з усіх книжок, за словами самого поета $[3,16]$.

Поет вивів узагальнюючий образ Матері, за яким стояли тисячі інших матерів, які зранку до ночі стояли в квадраті колгоспного поля.

Цей твір був високо оцінений як літературознавцями, так і звичайними українськими читачами. Так, відомий український письменник Дмитро Білоус зазначав: « $\mathbb{C}$ твори непроминальні, значущі, такі, що відображають не лише певні явища життя, а й саму епоху» [1, с.120]. До кожного розділу поеми поет добирає як епіграф рядки із трудової книжки. I сухі цифри виливаються у пекучі образи, які емоційно і правдиво висвітлюють історію глуму над українською нацією. Це і «Віяла мати жито», «Накидала гній», «Місила глину», «Копала канавки», «Накидала попіл», «Зрізала 46 
капусту», «Ніч над буряками», «Верстат», «Жала жито», «В'язала жито», «Коноплі», «Соняшники» та інші. Це ті роботи, які сьогодні здаються якоюсь божевільною вигадкою, але в ті часи вони були щоденною жорстокою реальністю, яка заганяла матерів у круті глиняні заміси, щоб вижати з них останні сили:

УСЕ ДЛЯ ДЕРЖАВИ!

Нагадує гасло...

А для Людини?

Надривать жили в глині...

ЦЕ ВИ, МАМО, ВИ

НЕ ПІДВОДИТЕ ГОЛОВИ...

Бо ноги в замісі

Годин уже вісім... [3, с. 18].

I за таку тяжку працю людина отримувала 200 грамів дерті на день. Тому поет порушує тему справедливості, людської гідності, а також повного безправ'я жінок в Україні, адже чоловіки в більшості не вернулись додому і увесь тягар лягав на плечі матерів. Автор щораз пише слово Мама з великої літери, віддаючи пошану за всі перенесені муки.

Як зазначає відомий літературознавець, академік Микола Жулинський «образ матері як берегині українського роду є наскрізною метафорою, символічним ключем, яким поет відкриває двері у світ жахливого минулого, спотвореного комуністичним режимом повоєнного дитинства, у світ рабського приниження людини, плюндрування моральних засад буття, традицій, віри, любові до рідного краю» [2, с. 131].

Третя книга тетралогії « Трагічні етюди» повністю побудована на архівних матеріалах та історичних документах, свідченнях очевидців, на листах-відгуках про часи голодомору, геноциду, репресій та колективізації (1921-1922,1932 - 1933, 1937, 1947, 1949 рр.). Ця книга $\epsilon$ вироком-осудженням комуністичному режиму. I наскрізним образом невмирущості , доброти та жертовності у цій книзі є образ української жінки як символу української долі.

У книзі прочитуємо образи-символи, які з простих повсякденних понять перетворилися на код повоєнного покоління: колгосп, веретено, полотно, трудодень, облігація, сепаратор, поштограма, тридцять третій, фінагент, об'їждчик, гектари... Жорна деспотизму і тиранії закрутилися. «Добровільна здача зерна», про яку йдеться у Постанові ЦК за підписом Сталіна від 1 січня 1933 року [3, с. 228], і за яку не будуть застосовані репресії - це витрушування останніх зернин, які могли залишитися схованими від тоталітарної машини. I їх потрібно було віддати, і нікого не цікавило, як вижити без хліба. Слідом за цією постановою ішли 
поштограми, телеграми, листи до ЦК, де звітувалося про кількість вмерлих, а хто ще дихав - того віддавали до суду.

Якщо історія подає лише сухі цифри та дати, за якими стоять певні події, то книга Миколи Томенка емоційно та образно торкається душі кожного, хто прочитає іiі, і навіть сьогоднішне покоління, для якого за словом «трудодень» нічого не стоїть, починає розуміти ту епоху краще, адже книга внесена до вивчення у шкільну програму.

\title{
Література:
}

1. Білоус Дмитро. Важка дорога до правди // Повертаюсь сьогодні до себе. Микола Томенко в колі друзів. К. Видавництво «Щек», 2017. C. 120 .

2. Жулинський Микола. Білі автографи української долі // Повертаюсь сьогодні до себе. Микола Томенко в колі друзів. К. Видавництво «Щек», 2017. С.131.

3. Томенко Микола. Трудова книжка матері. К. Видавництво «Фенікс», 2008. 307 с.

DOI https://doi.org/10.30525/978-9934-26-180-0-12

\section{АВТОКРЕАЦИЯ ТВОРЧЕСКОЙ ЛИЧНОСТИ В РАССКАЗАХ СБОРНИКА А. Н. ГАВРИЛОВА «ВОПЛЬ ВПЕРЕДСМОТРЯЩЕГО»}

\author{
Шеховцова Т. А. \\ доктор филологических наук, \\ профессор кафедры истории русской литературы \\ Харьковский национальный университет имени В. Н. Каразина \\ г. Харьков, Украина
}

Сборник А. Н. Гаврилова «Вопль впередсмотрящего» (2011) включает одноименную повесть, 15 рассказов и пьесу «Играем Гоголя». Рассказы, вошедшие в книгу, обладают внутренним единством и могут рассматриваться как авторский сборник-цикл или даже единый текст. Целостность этого «сборника в сборнике» обеспечивают сквозные темы и мотивы, повторяющиеся ситуации, внутренний сюжет, композиция, образ героя-повествователя. 